and in a lost commentary on the Parea Naturalia. ${ }^{44}$ Being dedicated to Neckam, the De motu cordis cannot be later than his death in 1217, and as Neckam himself seems to have been acquainted several years earlier with the Metaphysics, De anima, and De generatione et corruptione, ${ }^{45}$ it may go back to the beginning of the century. Even if we assign the latest possible limit to the treatise, it shows a wealth of Aristotelian citation such as we cannot find in any other Latin author of its time ${ }^{46}$ and its philosophy, based partly upon western Platonism and partly upon the older Arabic tradition, is singularly free from theological prepossessions. While Alfred's knowledge of Aristotle was derived in part from versions made from the Greek, ${ }^{47}$ we know from Roger Bacon and from internal evidence that he visited Spain, ${ }^{48}$ and he must be placed in the series of intermediaries between Arabic and western learning. With him, however, the movement passes from its mathematical and astronomical phase to that which occupied itself primarily with natural philosophy and metaphysics, and we are thus brought into the philosophical currents of the thirteenth century.

Chardes H. Haskins.

\title{
The Taxes upon Movables of the Reign of Edward III
}

THE appended table of the taxes upon personal property of the reign of Edward III is illustrative but not complete. After the first two subsidies, those of 1327 and 1332, had been assessed and collected, the system which had been developing for over a century was changed. The subsidy of 1334, with its special methods of assessment, marks the transition from the old to the new. After that date the charges against the various communities were standardized; in theory the amount paid by the communities of the boroughs, cities, and townships towards a subsidy was, after 1334, the same as was paid in that year. A table of

4 The library of Beauvais cathedral possessed in the seventeenth century 'Alfredus Anglicus in Aristotelem de mundo et celo, de generatione et corruptione, de anima, do somno et vigilantia, de morte et vita, de colore celi': Omont, Recherches our la bibliotheque de I'eglise cathedrale de Beauvais, from the Memoires de I Academie des Inscriptions, xl (Paris, 1914), p. 48, no. 143. The other treatises attributed to Alfred by the older bibliographers (Tanner, p. $37 \mathrm{f}$.) have not been confirmed by rocent studies. Steinschneider, Europdische Uebersetzungen, pp. 4, 7, does not identify the translator of the appendix to the Meteorologica, whom he calls, after certain manuscripts, Aurelius.

a Haskins, $A$ List of Text-books from the close of the Twelfth Century, in Harvard Studies in Classical Philology, xx. 85-7, 92 (1009).

4 Baenmker, p. 33. 47 Id., pp. 36-41.

10 Opus Maius, ed. Bridges, i. 67; Compendium Studii, ed. Brewer, p. 471; Baeumker, p. 23. 
all the taxes upon movables levied after that date would, therefore, only show the variations, never large, from the normal fixed charge. I give as a specimen the returns for only one of the later subsidies, that of the first year of the triennial grant of 1352, but I do not include in this table the returns from the wool subsidies or from the ninth of corn, wool, and lambs, together with the accompanying taxes, which, though they may be regarded as taxes upon movables, were too unusual in character to be here considered.

The methods of assessing and collecting the taxes upon movables were altered in consequence of the corrupt practices alleged to have been used in levying the subsidy granted in 1332. ${ }^{1}$ In order to prevent as far as possible such irregularities several expedients were adopted in 1334. ${ }^{2}$ Two persons, one an ecclesiastic, usually an abbot or prior, and the other a layman, who was commonly a crown official, were directed to take charge of the assessment and collection. These commissioners were ordered to treat with the communities of the cities and boroughs and with the men of the townships and the tenants on ancient demesne, and to agree with them upon the sum to be paid to the king for the fifteenth and tenth. If the local people failed to come to terms, the head taxers and collectors, with a clerk to be chosen by them, were to make the assessment. The results of these agreements or special assessments of 1334 constituted, in theory at least, the amount that each unit of taxation was to pay for the future whenever a subsidy was levied.

During the remainder of the reign of Edward III there were twenty subsidies, of the type mentioned, levied upon the nation. When a subsidy was granted for two or three years it has been counted as two or three subsidies, for this was the effect of such grants. When the first, that of March 1336, was granted, the writs sent to the commissions of assessors and collectors directed them to take from each city, borough, and township the amourit that had been levied upon it in $1334 .^{3}$ The same procedure was followed in later years, the tax in every casse being the amount of the subsidy next preceding.

From this system it followed that, though the taxes. were called fifteenths and tenths, those figures no longer had any

1 Calendar of Patent Rolls, 1334-8, p. 38. Compare my paper in the Traneactions of the Royal Bistorical Society, 3rd ser., vii. 186-8, for cases of proved corrupt praction during the fourteenth century.

- The writs are printed in full in Rotuli Partiamentorum, ii. 447-8, and the names of the assors and collectors in the Calendar of Patent Rolls, 1334-8, pp. 38-40.

- Fine Roll, no, 136 (10 Edward III), m. 17. The clanse reads 'agaignaverimus vos ad petendam et recipiendam de singulis Civitatibus Burgis et villis in comitata Cantabrigie tam infra libertates quam extra tantam pecunie summam quantam nobis in tuno ultima conossione deoime et quintedecime earundem solverunt ${ }^{\text {' }}$, \&e. 
slgnificance. The grant of a fiftenth and tenth meant the grant of a fixed sum of money, about $£ 38,000$ - the amount levied in 1334 with the addition of the quota of Cumberland, Northumberland, and Westmorland, which were at that time excused because of their poverty. The fact that the total awount from the township was fixed tended to develop a settled apportionment of that sum among the lesser permanent divisions within its boundaries. The bailiffs of the manor of Cuxham after 1337 paid 32 shillings for the demesne farm whenever a subsidy was levied. ${ }^{4}$ In other cases the same tendency is seen to have been at work. ${ }^{5}$ Another result of the new system was the necessity of reassessment when devastation or other causes made it imposaible for the inhabitants to pay the fixed amount. Such reassessments were frequently made. ${ }^{8}$ When this was done the people of course tried to keep this reduced valuation, even though they had recovered from their losses, whereas the collectors of the subsidies, on behalf of the government, naturally wished to restore the older assessment. Several instances of such struggles are recorded, and the government usually won.?

In the following tables no account is taken of exemptions fron taxes, of failures to pay, or of deductions made on account of the expenses allowed the collectors by the government. The amounts recorded are the charges assessed against the counties or boroughs and not the amount received by the treasury. ${ }^{8}$ Because of the ravages of the Black Death the king in three instances reduced the amount payable, but by judicious management avoided the danger of lessening the amount that the government was to receive. In 1349 it was directed that the wages received by Iabourers in excess of the legal wages fixed that year should be levied upon and applied in aid of the subsidy. ${ }^{9}$ In 1352 the king ordered that the fines, amercements, and other issues arising from infractions of the Statute of Labourers should be used to alleviate the burden of the triennial fifteenth and tenth upon the nation. ${ }^{10}$ In both these cases, whereas the exchequer received the full amount of the subsidies, the taxes paid in various districts

- Merton College Muniments, nos. 5863, 5864, 5805, 5870, 5871, 5872, 5875, \&c.

- Cal. of Patent Rolls, 1345-8, p. 466, the caso of a hamlet. Sce also Rot. Parl., ii. $189 a$, for a similar instance.

- Seo, for example, Cal. of Close Rolls, 1337-9, pp. 496, 500, 530, 533; ibid. 1339-41, pp. 285, 290.

- The case of Walsoken, Westwalton, and some other townships of Norfolk was long drawn out and is a good illustration of this kind of struggle. See Cal. of Patent Rolls, 1345-8, p. 394, and Exchequer Lay Subsidies, 149/13, 238/11, 149/17, 149/31, 149-37 seqq.

- Compare my paper ante, xxviii. 517.

- A full discussion of this grant and its history may be found in Misa B. H. Putnam. The Enforcement of the Shatules of Labourers, pp. 100-0.

10 Ibid. pp. 106 seqq. 


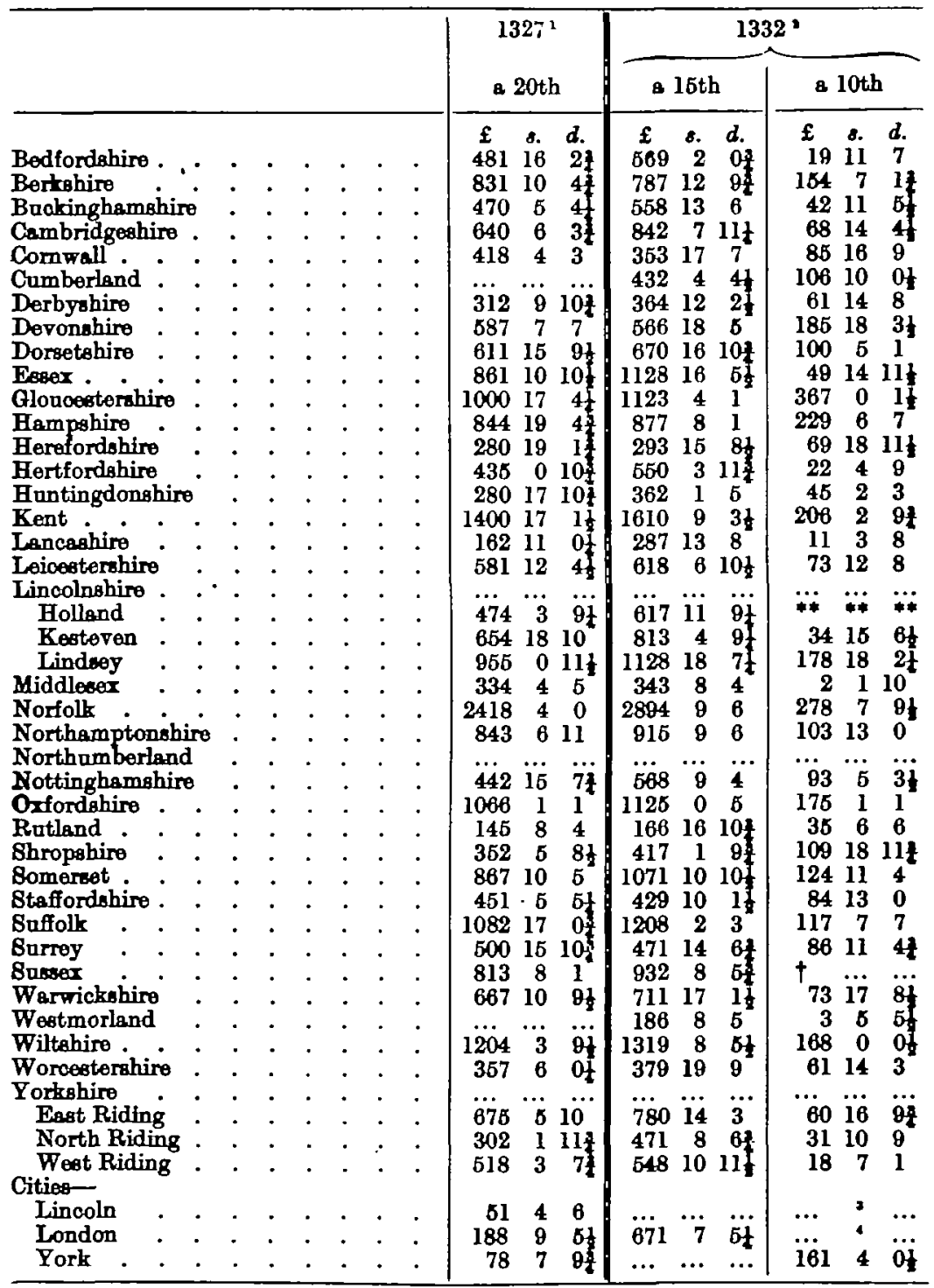

1 Lord Treasurar's Remembranoer, Enrolled Accounte, Subsidies, no. 8, m. 1.

Ibid. mm. 2-3.

Lincoln was acoounted for in Lindsey after 1327.

- London after 1327 was counted with the raral distriots and not with the cities and boroughs. This was due to a grant in the charter of 1327 ; 800 Birch, The Hiotorical Charters and Constitutional Dacuments of the City of London, 1887, p. 57. 


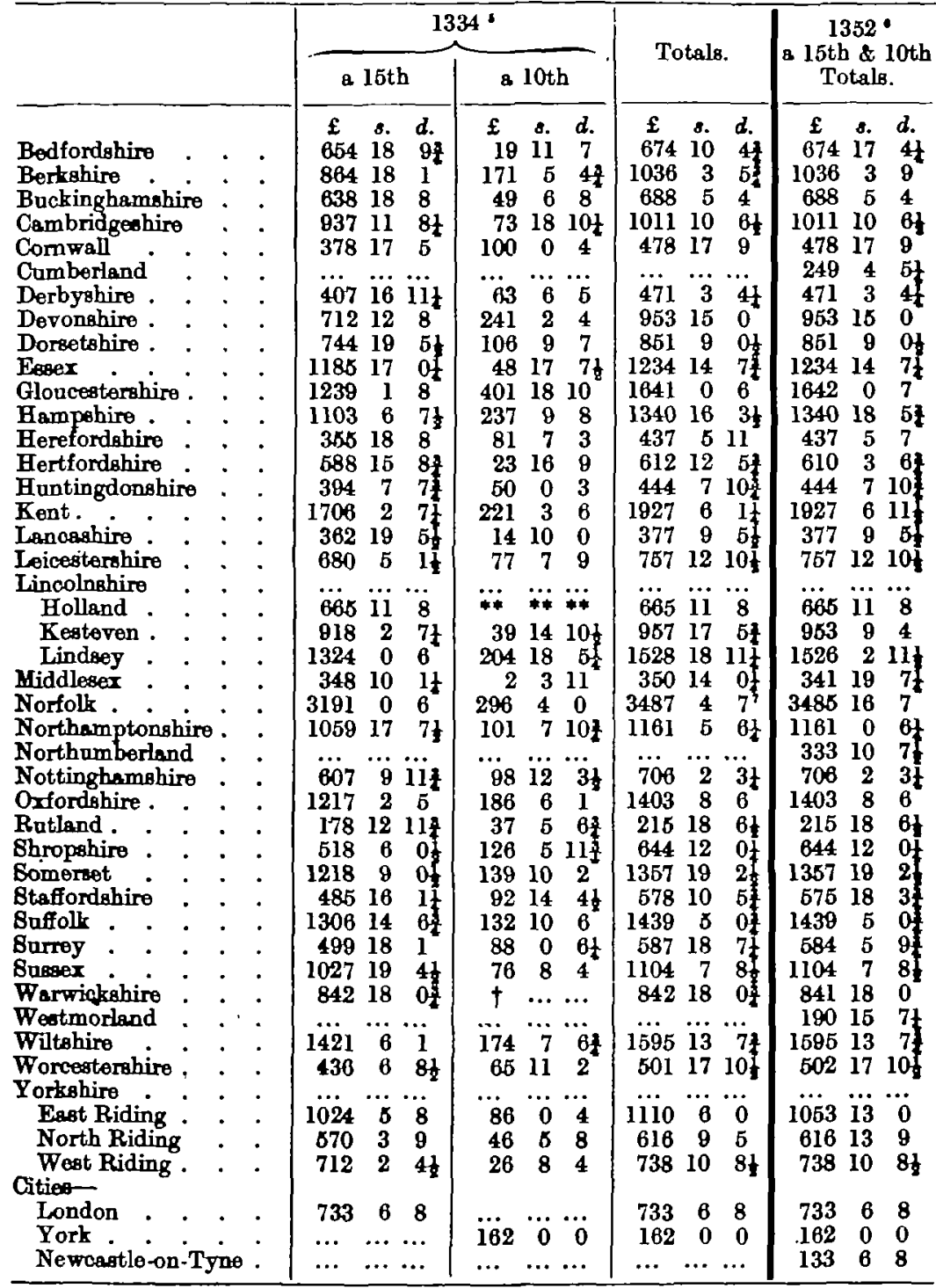

- Lord Treasuror's Romembrancer, Enrolled Accounts, Subsidies, no. 8, mm. 4-5.

- Reprinted from Mira Putnam, ubi rupra, appendix, pp. 315-21. I have to thank Misa Putnam for permission to borrow these figures.

This is the total which is given and which was accounted for. Fither the fifteenth or tenth, therefore, lacks one penny. 
were lowered by the amount of the penalties collected. A similar plan was used in 1357 when the king granted the money arising from escapes from prison and the chattels of felons and fugitives in alleviation of the burden of the subsidy of that year. ${ }^{11}$ In this instance the people seem to have paid the full amount of the tax at first and to have received the above-mentioned money later in the form of a cash rebate.

In explanation of the accompanying tables it may be stated that when the accounting of the enrolment of the subsidy is so faulty as to render useless the separate items of the fifteenths and tenths, their total is placed in one column and an obelus in the other. Whenever it is found that there were no cities or boroughs to contribute to the subsidy, this fact is indicated by asterisks.

Some changes have been made in the figures given in the enrolled accounts of the subsidies in order to make the tables uniform. To the tenth of Gloucestershire in 1332 the contribution of Bristol, $£ 200$, has been added, though that borough accounted separately. ${ }^{12}$ Bristol's share of the subsidy of 1334 was $£ 220$, and that has also been added to the tenth of Gloucestershire. ${ }^{13}$ To the fifteenth of the East Riding of Yorkshire, 1334, $£ 100$ has been added for the foe of the archbishop of York in Beverley, ${ }^{14}$ and to the fifteenth $£ 31$ for Kingston-upon-Hull. ${ }^{15}$ To the tenth of

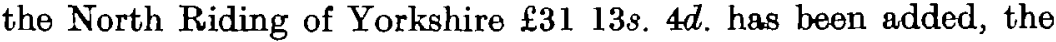
share of Scarborough in $1334 .^{16}$

JAMES F. WILLARD.

\section{The Earlier Career of Titus Livius de Frulovisiis ${ }^{1}$}

So little is known ${ }^{2}$ of the life of Titus Livius de Frulovisiis, the biographer of Henry V, that some further information about him, derived from a manuscript in the library of St. John's College, Cambridge, has its interest. The manuscript, which is described by Dr. James as no. 60 in his catalogue of the library's manuscripts, is, I believe, the unique and contemporary copy, executed for Titus Livius himself, of seven Latin comedies, ${ }^{3}$ five of which

$"$ The firat writs are found on Fine Roll, no. 158 (31 Edward $\amalg I)$, nt. 10.

12 Under both Gloucostershire and Somerset it is noted that Bristol accounted separately: Lord Treasurer's Remembrancer, Enrolled Accounts, Subsidies, no. 8, m. 2a. Seo also Cal. of Patent Rolls, 1330-4, p. 337.

13 Ibid. m. 4 d.

14 Lord Traasurer's Romembrancer, Enrolled Accounts, Subsidies, no. 14, m. 20. Compare Erohequer Lay Subsidy, 202/36.

16 Pipe RoH, no. 180 (9 Edward III), m. 38a, Adhuc Ebor'.

16 Lord Treasurer's Romembrancor, Enrolled Accounts, Subsidies, no. 8, m. 4a.

1 My thanks for help in writing this note are due to Sir John Sandya, and espeoially to Professor G. C. Moore-Smith, who kindly collated the text of the prologues.

? See for tho facts concerning him Kingsford, English Historical Literature in the Fifteenth Cenfury, pp. 50-6, and (less full) ante, xxr. $58 \mathrm{ft}$. 